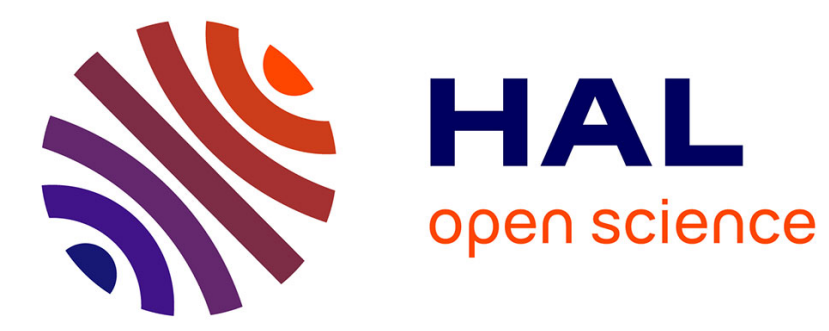

\title{
Modal meaning in Construction Grammar
}

Bert Cappelle, Ilse Depraetere

\section{To cite this version:}

Bert Cappelle, Ilse Depraetere. Modal meaning in Construction Grammar. Constructions and Frames, 2016, Modal meaning in Construction Grammar, 8 (1), pp.1-6. 10.1075/cf.8.1.01cap . hal-01495697

\section{HAL Id: hal-01495697 https://hal.science/hal-01495697}

Submitted on 26 Mar 2017

HAL is a multi-disciplinary open access archive for the deposit and dissemination of scientific research documents, whether they are published or not. The documents may come from teaching and research institutions in France or abroad, or from public or private research centers.
L'archive ouverte pluridisciplinaire HAL, est destinée au dépôt et à la diffusion de documents scientifiques de niveau recherche, publiés ou non, émanant des établissements d'enseignement et de recherche français ou étrangers, des laboratoires publics ou privés. 
Appeared as: Cappelle, Bert and Ilse Depraetere. 2016. Introduction: Modal meaning in Construction Grammar. [Introduction to special issue] Constructions and Frames 8:1, 1-6.

Introduction

\title{
Modal meaning in Construction Grammar
}

\author{
Bert Cappelle and Ilse Depraetere
}

Within the framework of Construction Grammar, modality remains a rather underexplored linguistic domain. This observation led to the organization of a workshop on modal meaning in Construction Grammar at ISLE 3, the third conference of the International Society for the Linguistics of English, held in Zürich in 2014. While attempts to analyse modal (and/or future) auxiliaries from this theoretical perspective are relatively scare, they are definitely not non-existent, and we could mention at least work by Bergs (2010), Boogaart (2009), Cappelle and Depraetere (2013), Cappelle and De Sutter (2010), Diewald (2006), Diewald and Smirnova (2011a, 2011b), Goldberg and Van der Auwera (2012), Hilpert (2008, 2013a, 2013b), Mortelmans (2000) and Wärnsby (2002). Boogaart and Fortuin (2016) provides a succinct general treatment of the subject and an overview of the literature. For the ISLE 3 workshop, we invited some of the authors who had analysed facets of modal meaning from the point of view of Construction Grammar, including those who were critical of its potential. We asked the speakers to look back and forward: five to ten years later, what was their view on the ways in which Construction Grammar could push the analysis of modal meaning further ahead? Likewise, we were interested to find out what Construction Grammar could gain from available analyses of modal meaning. The debate was enlightening and we decided to share the views put forward with the wider community. Each of the papers in this thematic issue addresses one or several of the following questions:

(a) Is Construction Grammar, with its holistic approach in terms of form-function pairings, suitable for the analysis of modal meaning in general and modal verbs in particular, which typically involve meaning in context? How can the pragmatics of modals be captured in this model? And if there is a way to do so, what can be gained from this endeavour, that is, how can the analysis of modals be improved?

(b) Do 'modal constructions' (constructions with modals) exist? If so, how can we identify them (and their development) empirically? And how can constructional meaning be represented or formalized?

(c) What does the analysis of modal meaning teach us about constructions? What can Construction Grammar gain from the analysis of modality?

This issue contains an opening paper by the editors, followed by three pairs of target and response papers by invited scholars. In the opening paper, Bert Cappelle and Ilse Depraetere attempt to integrate the second author's recently proposed multi-layered model of modal meaning into Construction Grammar. They propose that Construction Grammar needs to make a distinction between semantic and pragmatic information, and that the study of modal meaning benefits from recognizing the impact which larger lexico-grammatical environments around the modal auxiliary can have on the interpretation of that modal. A central notion in this paper is that of short-circuited interpretation, that is, a conventionalized interpretation directly associated with an expression. The notion of shortcircuited implicature was first used by Morgan (1977), but the authors extend it here to conventionalized semantic interpretations, that is, to the context-dependent selection of for instance an opportunity meaning over, say, a permission or ability meaning for can, and to conventionalized pragmatic interpretations other than implicatures. The authors base their analysis on various humorous instances of intentionally or non-intentionally misunderstood strings containing a modal, such as [NP can be so AdjP] or [Not if I can help it]. The language jokes, taken from The Simpsons, reveal that speakers know a wide variety of modal verb constructions with a conventionalized semantic interpretation and often also a conventionalized (in the sense of short-circuited) implicature or illocutionary force. 
Appeared as: Cappelle, Bert and Ilse Depraetere. 2016. Introduction: Modal meaning in Construction Grammar. [Introduction to special issue] Constructions and Frames 8:1, 1-6.

Anna Wärnsby takes epistemic may as a starting point for her discussion of Construction Grammar as a viable framework to study modal meaning. She argues that even a very brief sketch of the inheritance links among modal and other constructions shows that there is a "bewildering web of constructions", the contribution of each of which to the modal interpretation is hard to pin down. Moreover, epistemic constructions that are schematic or frequent (e.g. modal verb + state) are not any more or less inherently epistemic than any of those that are less schematic or frequent (e.g. epistemic may + be + Adj) and from that perspective Construction Grammar does not offer a better insight into the category of epistemic meaning in itself. These observations result in the conclusion that Construction Grammar is at best an adequate descriptive tool, but does not, in itself, offer clear answers to thorny questions concerning the monosemy and polysemy of modals, or cases of indeterminacy. Wärnsby also discusses examples in which elements of the context, left implicit in the utterance, determine whether the meaning expressed is epistemic or not. How can cases like these be handled and formalised in Construction Grammar? A first observation in Graeme Trousdale's response to Wärnsby's paper is that the detail required to capture the complex web of modal constructions falls out from the nature of modal meaning itself: the modals constitute a particularly messy category. In his view not all of the strings mentioned in the paper are different constructional types; he further observes that multiple inheritance indeed has an important role to play, also in a more general way and in other domains. He shows that Wärnby's analysis in terms of a decision tree may well be compatible with a constructionist approach to context and co-text and one based on semantic maps. While work has been done on how to formalize contextual properties, this is an ongoing challenge in research in Construction Grammar. The role of implicit information is linked to the general question of how schematic a construction can get and that of the relationship between world knowledge and linguistic form, which Trousdale argues is an issue for any model of language.

While Anna Wärnsby's paper is basically concerned with the suitability of Construction Grammar for the analysis of the meaning of modals, Martin Hilpert explores how the framework can advance our knowledge of modal auxiliaries and their change over time. In an earlier study, Hilpert (2013b) created what is known as a semantic vector space of the nine core English modal auxiliaries (can, could, may, might, must, shall, should, will and would), using a technique based on quantitative distributional evidence about similarities or differences in the contexts of linguistic items. On the basis of diachronic data from the Corpus of Historical American English (COHA), he showed that the nine core modals differ with regard to their collocating material and that these differences can be interpreted in terms of associations to different dimensions of textual registers (Biber 1988). For example, the modal auxiliary shall has become ever more infrequent and is now primarily used in formal and informative text types, whereas would, once standing out among the other modals as highly epistemic and interpersonally 'involved', has gravitated towards the other modals in terms of its collocational profile. Hilpert also found that the modal auxiliary may has undergone a semantic shift towards more epistemic meanings. In this issue, Hilpert follows up on this result and identifies the contextual elements that are chiefly responsible for the diachronic semantic shift of may. Changing cooccurrence frequencies in the COHA over the past two centuries reveal that may has come to be used more often with verbs that are abstract, stative, and unrelated to animate subjects, such as depend, exist, involve, or indicate. Hilpert emphasises the merits of a usage-based, constructionist perspective on English modal expressions, which aims to capture speakers' knowledge of a modal verb in terms of the associations this verb has with a large number of lexical items. The changes in co-occurrence patterns of a modal verb are then best understood as changes in a constructional network of connections. Bert Cappelle and Ilse Depraetere respond acceptingly of this usage-based, constructionist view proposed by Hilpert and propose to widen the scope of attention to associations between the modal verb and other linguistic elements than just the following lexical verb. Taking must as an example, they argue, on the basis of collocational strength data obtained from the British National Corpus, that speakers may have stored such sequences as I must confess, You must be joking, Care must be taken ... or even It must be remembered that ..., all of which are longer than two words.

Elizabeth Closs Traugott's contribution is focussed on the representation and formalization of constructionalization, that is, the creation of form new $_{-}$meaning $_{\text {new }}$ pairs in particular contexts. She shows how semantic maps, which capture cross-linguistic generalizations pertaining to overlap and connections among meanings, can be exploited within a Construction Grammar framework focussed 
Appeared as: Cappelle, Bert and Ilse Depraetere. 2016. Introduction: Modal meaning in Construction Grammar. [Introduction to special issue] Constructions and Frames 8:1, 1-6.

on form-meaning pairs in the grammar of a specific language. Semantic maps meet to a considerable extent the requirements of Construction Grammar: they can account for changes both at the schematic and the micro levels, overtly linking meaning (semantic, pragmatic and discourse functional) with form (syntactic, morphological, phonological), they show the connectivity of changes combined with proximity in terms of both form and meaning and they account for networks with other constructions in a conceptual space. However, semantic maps need to be reconceptualised so as to represent aspects of networks of hierarchic relationships too. Traugott argues that two types of semantic map should be distinguished, which represent form-meaning pairings at different levels of abstraction and that are integrated with one another: (a) schema-construction maps (SCM), which represent relationships between abstract, conceptual schemas linked to form, and (b) micro-construction maps (MCM), which represent relationships between specific constructions. She makes her case on the basis of the analysis of the development of the marginal modals BETTER, RATHER and SOONER. The diachronic and synchronic study of these forms leads Traugott to conclude that these modals do not form a unified schema, as BETTER, unlike the other two forms, is future oriented and is often used performatively. The semantic trajectory through time of each of the forms is first represented in terms of Van der Auwera and Plungian's (1998) modal map and Narrog's (2012) semantic space, both of which represent semantic connectivity and semantic proximity. She then unifies aspects of both models into MCMs and SCMs. Both these types of construction maps are generalizations made by linguists and Traugott devotes some space to the question of whether they also represent speakers' knowledge of their language. She hypothesizes that they do, as "organizing factors in the constructicon". In his response to Elizabeth Closs-Traugott's paper, Alexander Bergs underlines the great potential of the model outlined, pleading for an even more enhanced attention to onomasiological relations in a constructional network. He also suggests that Traugott's model of semantic maps should be applied to further case studies of constructions that belong to other conceptual domains and that may exhibit diachronic change along less gradual paths than modal constructions do. Finally, he invites the reader to take advantage of new publication channels which may enable us to abandon the constraining, twodimensional static representations on paper and to visualize complex constructional networks in fresh ways, thus perhaps spawning new modes of thinking and new insights about current problems.

\section{References}

Bergs, Alexander. 2010. Expression of futurity in contemporary English: a Construction Grammar perspective. English Language and Linguistics 14.2: 217-238.

Biber, Douglas. 1988. Variation across speech and writing. Cambridge: Cambridge University Press.

Boogaart, Ronny. 2009. Semantics and pragmatics in construction grammar: the case of modal verbs. In Bergs, Alexander and Gabriele Diewald (eds.), Contexts and constructions. Amsterdam: John Benjamins. 213-41.

Boogaart, Ronny and Egbert Fortuin. 2016. Modality and mood in cognitive linguistics and construction grammars, In: Nuyts, Jan and Johan Van der Auwera (eds.), Oxford Handbook of Modality and Mood. Oxford: Oxford University Press, pp. 514-533.

Bybee, Joan B. 2010. Language, usage and cognition. Cambridge: Cambridge University Press.

Cappelle, Bert and Ilse Depraetere. 2013. Modal verbs from a construction grammar perspective. Fifth International AFLiCo Conference "Empirical Approaches to Multi-modality and to Language Variation”, Université Lille 3, Villeneuve d'Ascq, France, 15-17 May 2013.

Cappelle, Bert and Gert De Sutter. 2010. Should vs. ought to: A corpus-based multivariate analysis. Sixth International Conference on Construction Grammar (ICCG-6), Charles University, Prague, Czech Republic, 3-5 September 2010.

Diewald, Gabriele (2006). 'Context types in grammaticalization as constructions'. Constructions SV19.

Gabriele Diewald \& Elena Smirnova (eds.). 2011a. Modalität und Evidentialität. Fokus 37. Trier: Wissenschaftlicher Verlag. 
Appeared as: Cappelle, Bert and Ilse Depraetere. 2016. Introduction: Modal meaning in Construction Grammar. [Introduction to special issue] Constructions and Frames 8:1, 1-6.

Gabriele Diewald \& Elena Smirnova. 2011b. The German evidential constructions and their origins. A corpus based analysis. In: Tanja Mortelmans, Jesse Mortelmans \& Walter De Mulder (eds.), In the mood for mood. Amsterdam, New York. Rodopi (Cahiers Chronos 23), 81-100..

Goldberg, Adele \& Johan van der Auwera (2012). 'This is to count as a construction'. Folia Linguistica 46, 109-32.

Hilpert, Martin. 2008. Germanic Future Constructions. A usage-based approach to language change. Amsterdam: John Benjamins.

Hilpert, Martin. 2013a. Constructional change in English: developments in allomorphy, word formation and syntax. Cambridge: Cambridge University Press.

Hilpert, Martin. 2013b. Die englischen Modalverben im Daumenkino: Zur dynamischen Visualisierung von Phänomenen des Sprachwandels. Zeitschrift für Literaturwissenschaft und Linguistik 42, 67-82.

Morgan, Jerry L. 1977. Two types of convention in indirect speech acts. Technical report No. 52. University of Illinois at Urbana-Champaign.

https://www.ideals.illinois.edu/bitstream/handle/2142/17765/ctrstreadtechrepv01977i00052_opt.pdf?s eque.

Mortelmans, Tanja (2000). 'Konjunktiv II and Epistemic Modals in German: A division of Labour', in: Ad Foolen \& Frederike van der Leek (eds.) Constructions in Cognitive Linguistics. Amsterdam/Philadelphia: Benjamins, 191-215.

Stefanowitsch, Anatol. 2003. A construction-based approach to indirect speech acts. In Panther, Klaus-Uwe and Linda Thornburg (eds.), Metonymy and pragmatic inferencing. Amsterdam: John Benjamins. 105-26.

Traugott, Eizabeth Closs. 2010. Revisiting subjectification and intersubjectification. In Davidse, Kristin, Lieven Vandelanotte and Hubert Cuyckens (eds.), Subjectification, Intersubjectification and Grammaticalization. Berlin: Mouton de Gruyter, 29-71.

Van der Auwera, Johan and Vladimir Plungian. 1998. Modality's semantic map, Linguistic Typology 2: 79-124.

Wärnsby, Anna 2002. Modal constructions? The Department of English in Lund: Working Papers in Linguistics 2.

\author{
Authors' addresses \\ Université Lille 3 - SHS \\ UMR 8163 STL \\ Pont de Bois \\ BP 60149 \\ 59653 Villeneuve d'Ascq \\ France
}

bert.cappelle@univ-lille3.fr

ilse.depraetere@univ-lille3.fr 